\title{
Redox interactions of technetium with neptunium in acid solutions
}

\author{
Maciej Chotkowski ${ }^{1,2}$
}

Received: 1 March 2018/Published online: 17 May 2018

(C) The Author(s) 2018

\begin{abstract}
Redox interaction of reduced technetium forms and technetium(VII) with neptunium(III), neptunium(IV) and neptunium(VI) have been investigated using electrochemical and spectroscopic (Vis-NIR) techniques. The neptunium species most stable in $4 \mathrm{M} \mathrm{H}_{2} \mathrm{SO}_{4}$, i.e. $\mathrm{Np}$ (IV) ions, do not reduce $\mathrm{Tc}$ (VII) in contrast to $\mathrm{Np}$ (VI) ions which oxidize Tc(IV) species to $\mathrm{Tc}(\mathrm{VII})$. The interaction of pertechnetates with $\mathrm{Np}$ (III) leads to formation of $\mathrm{Tc}(\mathrm{IV})$ species. The Vis-NIR measurements showed the generation of intermediate $\mathrm{Tc}(\mathrm{V})$ and $\mathrm{Np}(\mathrm{V})$ forms during the oxidation of $\mathrm{Tc}(\mathrm{IV})$ and competitive reduction of $\mathrm{Np}(\mathrm{VI}) . \mathrm{Tc}(\mathrm{V})$ and $\mathrm{Np}(\mathrm{V})$ forms are characterised by the bands at 460 and $980 \mathrm{~nm}$ respectively.
\end{abstract}

Keywords Technetium · Neptunium · Electrochemistry · Vis-NIR

\section{Introduction}

Technetium and neptunium are artificial elements produced in relatively large amounts in nuclear power generation systems $[1,2]$. The main technetium radioisotope presents in spent nuclear fuels (SNFs) is long living ${ }^{99} \mathrm{Tc}\left(\mathrm{T}_{1 / 2}\right.$ $=2.13 \times 10_{5}$ year) which is a product of beta minus decay of ${ }^{99}$ Mo generated as a product of fission reaction of ${ }^{235} \mathrm{U}$. The ${ }^{99} \mathrm{Tc}$ yield in fission products is at the level of $6 \%$ [1], which corresponds to $1 \mathrm{~kg}$ of Tc in 1 ton of SNF from a typical LWR (burnup of $45 \mathrm{GWd} / \mathrm{tHM})[3] .{ }^{237} \mathrm{~Np}\left(\mathrm{~T}_{1 / 2}\right.$ $=2.14 \times 10_{6}$ year $)$ as the product of $(\mathrm{n}, 2 \mathrm{n})$ reaction with ${ }^{238} \mathrm{U}$ [1, 2] is generated with a quantity of $0.40-0.48 \mathrm{~kg}$ in 1 ton of SNF [4]. Due to the fact that both elements are long living radioisotopes they pose a potential long term radiological risk.

Chemical properties of $\mathrm{Tc}$ and $\mathrm{Np}$ in aqueous media are complicated by the fact that both elements can exist in many oxidation states. Therefore, the redox interactions between reduced technetium species with a strongly oxidizing $\mathrm{Np}(\mathrm{VI})$ are expected to occur $[5,6]$ but they have

Maciej Chotkowski

mchotk@chem.uw.edu.pl

1 Faculty of Chemistry, University of Warsaw, Pasteura 1, 02-093 Warsaw, Poland

2 Biological and Chemical Research Centre, University of Warsaw, Żwirki i Wigury 101, 02-089 Warsaw, Poland not been thoroughly investigated and they are not fully explained yet. Reported schemes of technetium processes taking place in aqueous solutions in the presence of actinides (e.g. $\mathrm{U}, \mathrm{Np}$, or $\mathrm{Pu}$ ) show a very complex redox behavior of the former which involves also unstable $+\mathrm{V}$, + VI oxidation states [7-9]. Noteworthy is the fact that susceptibility of $\mathrm{Tc}(\mathrm{IV})$ species towards the oxidation strongly depends on their structure [10].

According to Rotmanov et al. [11] the dissolution of metallic Tc in an acid is accompanied by generation of reduced Tc species characterized spectroscopically by a band near $480 \mathrm{~nm}$. These authors attribute this signal to $\mathrm{Tc}(\mathrm{V})$ ions. This is in line with conclusions of Maslennikov et al. [12] who reported that technetium species present in nitric acid solutions, most likely $\mathrm{Tc}(\mathrm{V})$ can be determined using a Vis band with the maximum at $480 \mathrm{~nm}$. The structure of $\mathrm{Tc}(\mathrm{V})$ in concentrated sulfuric acid solutions has been investigated by Poineau et al. [13] and described as $\mathrm{TcO}^{3+}$ characterised by a broad band in the Vis region 650-800 $\mathrm{nm}$. The other than described above technetium species were reported by Paquette [14]. These authors determined spectroscopically Tc(III) ions in slightly basic media using weak bands in Vis range at 470 (and 630) $\mathrm{nm}$. This observation is in line with our results which also strongly suggest generation of Tc(III) species characterized spectroscopically by the band at $440 \mathrm{~nm}$ [10]. The spectroscopic properties of main $\mathrm{Tc}(\mathrm{IV})$ species present in aqueous solutions, i.e. $\mathrm{TcO}^{2+}$ and $\mathrm{Tc}(\mathrm{III} / \mathrm{IV})$-polymers [15-17]. 
The goal of this work was to study the redox interactions between $\mathrm{Tc}$ and $\mathrm{Np}$ species in aqueous media. In most of the papers devoted to this topic the various forms of Tc and $\mathrm{Np}$ were formed already in the mixture containing both elements by means of e.g. oxidation [7, 9]. Under such conditions, however, identification of investigating species is not always possible due to e.g. overlapping absorption bands of various forms of both elements. Therefore, the present work involves a separate synthesis of Tc and Np species of interest. These species were then identified and characterised by means of electrochemical and spectrophotochemical measurements.

\section{Experimental}

Aqueous stock solutions of $\mathrm{Tc}(\mathrm{VII})$ and $\mathrm{Np}$ (IV) were prepared by dissolving potassium pertechnetate and neptunium dioxide in sulfuric acid solution, respectively. The concentration of $\mathrm{TcO}_{4}{ }^{-}$in the prepared stock solution was $19.6 \mathrm{mM}$ while the $\mathrm{Np}$ concentration in the stock solution was $20.3 \mathrm{mM}$. The presence of only a single form of $\mathrm{Np}$ species in green stock solution (Np(IV)), which was stable over a long time, was confirmed by separate spectrophotometric titrations with $\mathrm{KMnO}_{4}$.

\section{Preparation of Tc species}

Technetium with oxidation states other than +7 , which are referred to as "reduced Tc" hereafter, were generated by the methods described previously [15]. The experiments were carried out by using a home made electrochemical thin layer cell with a reticulated vitreous carbon (RVC, thickness $2 \mathrm{~mm}, 100$ ppi porosity, supplied by ERG Aerospace Corporation), a gold foil and an $\mathrm{Ag} / \mathrm{AgCl}$ in $3 \mathrm{M} \mathrm{NaCl}$ as a working-, counter- and reference electrode, respectively. Such generated Tc forms were subsequently eluted from the pores of the working electrode (RVC) using $4 \mathrm{M} \mathrm{H}_{2} \mathrm{SO}_{4}$.

\section{Preparation of Np species}

Two oxidation states of $\mathrm{Np}$ were synthesized in this study: $\mathrm{Np}$ (III) (as $\mathrm{Np}^{3+}$ ) and $\mathrm{Np}$ (VI) (as $\mathrm{NpO}_{2}{ }^{2+}$ ). $\mathrm{Np}$ (III) and $\mathrm{Np}(\mathrm{VI})$ species were generated electrochemically by oxidation or reduction of $\mathrm{Np}$ (IV) stock solution, respectively. A three electrode cell system was used with working and counter electrodes made of platinum meshes and a $\mathrm{Ag}$ / $\mathrm{AgCl}$ in $3 \mathrm{M} \mathrm{KCl}$ reference electrode. The cathodic and anodic compartments of the cell were separated by a vycor glass frit. $\mathrm{Np}^{4+}$ and $\mathrm{Np}^{3+}$ are considered as weak and strong reducing agents, respectively, while $\mathrm{NpO}_{2}{ }^{2+}$ is a strong oxidizer. The standard redox potential of the
$\mathrm{Np}(\mathrm{IV}) / \mathrm{Np}$ (III) couple is relatively low and equals $0.155 \mathrm{~V}$. Thus, one may assume that the electrogeneration of appropriate $\mathrm{Np}$ reduced species should not be difficult. It turned out, however, that the electrochemical procedures leading to obtaining selected $\mathrm{Np}$ species [18] in $4 \mathrm{M}$ $\mathrm{H}_{2} \mathrm{SO}_{4}$ were ineffective. Therefore, low cathodic $(-2 \mathrm{~V})$ and high anodic $(+2.2 \mathrm{~V})$ potentials were applied to the platinum electrode to generate of $\mathrm{Np}$ (III) or $\mathrm{Np}(\mathrm{VI})$ ions, respectively.

Figure 1 presents the Vis-NIR spectra of $\mathrm{Np}(\mathrm{III})$, $\mathrm{Np}(\mathrm{IV})$ and $\mathrm{Np}(\mathrm{VI})$ species prepared in this study. The spectra were recorded using a Varian Cary 5 spectrophotometer. It is obvious that the shape of the spectrum clearly reflects the oxidation state of $\mathrm{Np}$. That is, for $\mathrm{Np}(\mathrm{IV})$ one notes three characteristic peaks with the maxima near 730 , 820 and $980 \mathrm{~nm}, \mathrm{NpO}_{2}{ }^{2+}$ is characterized by a wave at $1220 \mathrm{~nm}$, while for $\mathrm{Np}$ (III) several sharp absorption bands appear in the 500-900 $\mathrm{nm}$ range. The positions of all these absorption bands are in good agreements with the literature data [19]. The wavelength at $400 \mathrm{~nm}$ can also be attributed to $\mathrm{NpO}_{2}{ }^{2+}$ in the solution. The authors of Ref. [19] report a strong increase in the absorbance of $\mathrm{Np}(\mathrm{VI})$ at wavelengths below 430 nm (Fig. 2 in Ref. [19]). The lack of any signals in the range of 600-1100 $\mathrm{nm}$ excludes the existence of other than $\mathrm{Np}(\mathrm{VI})$ neptunium species, such as those in oxidation states of + III, + IV or + V. Further on, $\mathrm{Np}$ (VII) is relatively stable only in alkaline environments [6].

According to the literature data [6], +5 is the most stable oxidation state of $\mathrm{Np}$ present in aqueous solutions at broad $\mathrm{pH}$ range. In strongly acidic media (4 $\mathrm{M} \mathrm{H}_{2} \mathrm{SO}_{4}$ ) $\mathrm{Np}(\mathrm{V})$ ions disproportionate to $\mathrm{Np}(\mathrm{IV})$ and $\mathrm{Np}(\mathrm{VI})$ [20] according to Eq. 1:

$2 \mathrm{NpO}_{2}^{+}+4 \mathrm{H}^{+} \rightleftharpoons \mathrm{Np}^{4+}+\mathrm{NpO}_{2}^{2+}+\mathrm{H}_{2} \mathrm{O}$

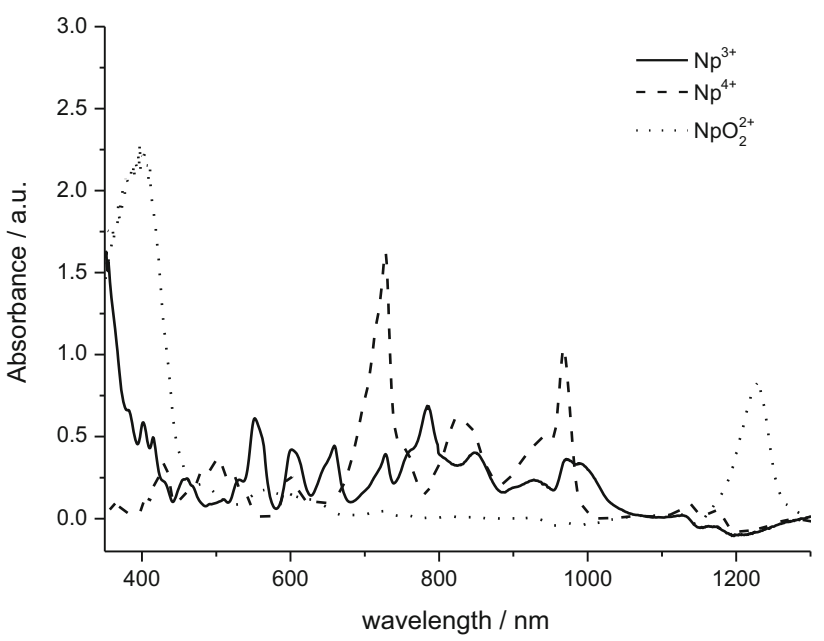

Fig. 1 Vis-NIR spectra of $20.3 \mathrm{mM} \mathrm{Np}^{3+}, \mathrm{Np}^{4+}$ and $\mathrm{NpO}_{2}{ }^{2+}$ in $4 \mathrm{M}$ $\mathrm{H}_{2} \mathrm{SO}_{4}$ 
The equlibrium constant of reaction (1) increases from 0.13 to 200 with increasing acidity from $5.34 \mathrm{M} \mathrm{HClO}_{4}$ to $8.67 \mathrm{M} \mathrm{HClO}_{4}$, respectively [21]. It is expected that the equilibrium constant of reaction (1) in sulfuric acid solutions with the same acidity as the above mentioned $\mathrm{HClO}_{4}$ solutions should be also relatively high due to complexation of $\mathrm{Np}^{4+}$ by the sulfates. The sulfates accelerate the $\mathrm{Np}(\mathrm{V})$ disproportionation [22].

\section{Tc-Np interaction studies}

The solutions containing mixtures of as-prepared solutions of $\mathrm{Tc}$ and $\mathrm{Np}$ with different compositions were used in studies on the interaction between these radioactive elements. Cyclic voltammetry was performed to investigate the red-ox processes and stability of Tc and Np species in the mixture, their identity was evaluated on the basis of Vis-NIR measurements results.

Before starting the electrochemical measurements with the Tc-Np mixture, the mixed sample was equilibrated for $45 \mathrm{~min}$. The measurements were carried out in a three electrode cell system with an $\mathrm{Au}$ rod, $\mathrm{Pt}$ mesh and $\mathrm{Ag} / \mathrm{AgCl}$ in $3 \mathrm{M} \mathrm{NaCl}$ as a working, counter- and reference electrode, respectively. The anodic and cathodic compartments of the cell were separated by a vycor glass frit. Under the conditions studied, $\mathrm{Np}(\mathrm{VI})$ is expected to oxidize Tc "reduced" species while $\mathrm{Np}(\mathrm{III})$ is expected to reduce pertechnetates. In order to complete such a redox processes of Tc, the neptunium concentration was always in excess in respect to the technetium.

All the potentials mentioned hereafter are referred to the $\mathrm{Ag} / \mathrm{AgCl} / 3 \mathrm{M} \mathrm{KCl}$ reference electrode. A potentiostat/galvanostat Autolab PGSTAT101 from Metrohm was used in the electrochemical experiments.

\section{Results and discussion}

Figure 2 presents cyclic voltammograms (CVs) recorded for gold electrodes in $4 \mathrm{M} \mathrm{H}_{2} \mathrm{SO}_{4}$ containing pertechnetates with and without addition of $\mathrm{Np}(\mathrm{III}), \mathrm{Np}(\mathrm{IV})$ or $\mathrm{Np}(\mathrm{VI})$. In the absence of $\mathrm{Np}$ species (Fig. 3, solid line) the current due to pertechnetates reduction starts at ca. $0.6 \mathrm{~V}$ with the peak maximum at ca. $0.55 \mathrm{~V}$, in agreements with previous reports [23]. This peak corresponds to the reduction of $\mathrm{Tc}(\mathrm{VII})$ to $\mathrm{Tc}(\mathrm{IV})$ via unstable $\mathrm{Tc}(\mathrm{V})$ forms [23], e.g.:

$$
\begin{aligned}
& \mathrm{Tc}^{\mathrm{VII}} \mathrm{O}_{4}^{-}+6 \mathrm{H}^{+}+2 \mathrm{e}^{-} \rightarrow \mathrm{Tc}^{V} \mathrm{O}^{3+}+3 \mathrm{H}_{2} \mathrm{O} \\
& 3 \mathrm{Tc}^{\mathrm{V}} \mathrm{O}^{3+}+3 \mathrm{H}_{2} \mathrm{O} \rightarrow 2 \mathrm{Tc}^{\mathrm{IV}} \mathrm{O}^{2+}+\mathrm{Tc}^{\mathrm{VII}} \mathrm{O}_{4}^{-}+6 \mathrm{H}^{+}
\end{aligned}
$$

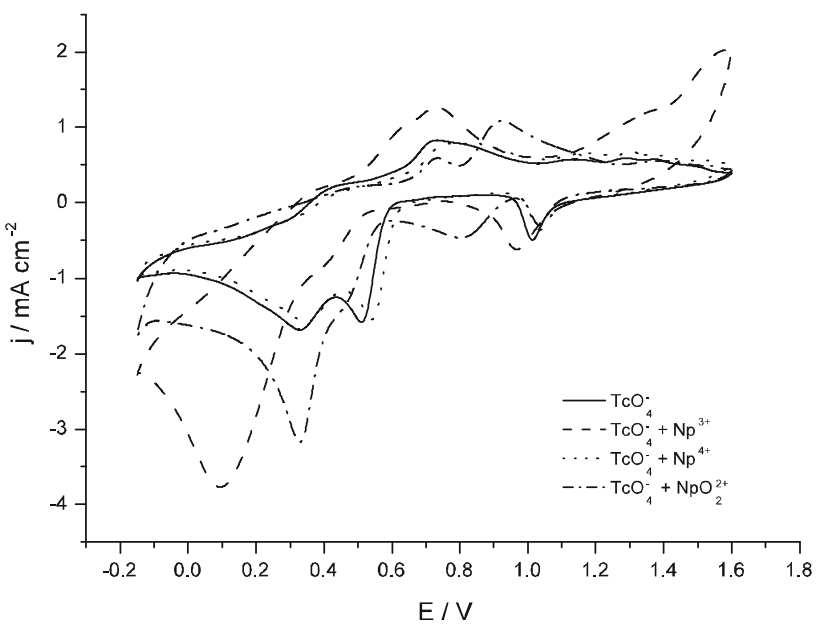

Fig. 2 Cyclic voltammograms of $5 \mathrm{mM} \mathrm{TcO}_{4}{ }^{-}$and $11 \mathrm{mM} \mathrm{Np(III,}$ $\mathrm{IV}$ or $\mathrm{VI})$ in $4 \mathrm{M} \mathrm{H}_{2} \mathrm{SO}_{4}$. $\mathrm{Au}$ electrode, room temperature, $v=200 \mathrm{mV} \mathrm{s}^{-1}$
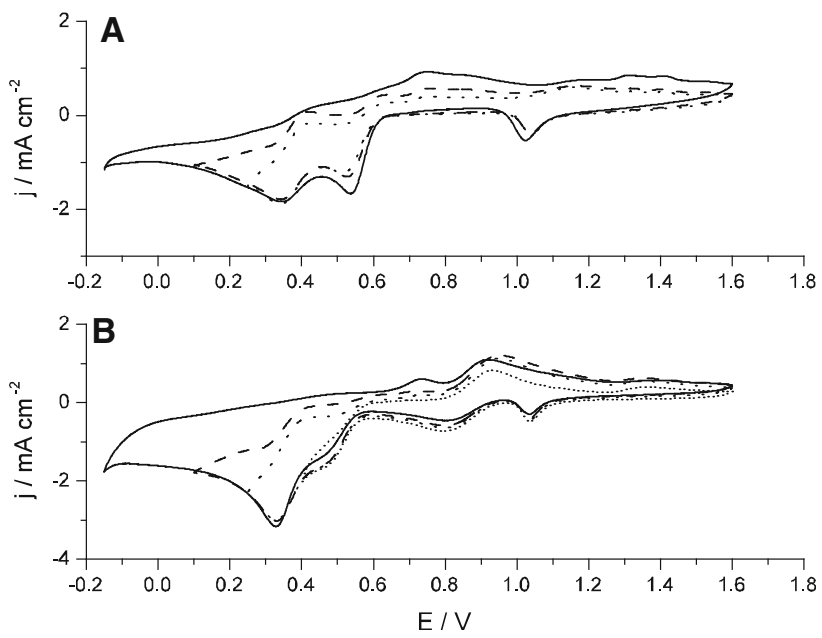

Fig. 3 Cyclic voltammograms recorded for Au electrode in $\mathbf{A} 5 \mathrm{mM}$ $\mathrm{TcO}_{4}{ }^{-}+11 \mathrm{mM} \mathrm{Np}{ }^{4+}+4 \mathrm{M} \mathrm{H}_{2} \mathrm{SO}_{4}$, B $5 \mathrm{mM} \mathrm{TcO}_{4}{ }^{-}+11 \mathrm{mM}$ $\mathrm{NpO}_{2}{ }^{2+}+4 \mathrm{M} \mathrm{H}_{2} \mathrm{SO}_{4}$ and various cathodic vertex potentials, $v=200 \mathrm{mV} \mathrm{s}^{-1}$

The second broad and poorly shaped cathodic wave seen at lower potentials $(0-0.45 \mathrm{~V})$ is due to various electrochemical and chemical reactions of technetium compounds with various oxidation states, mainly + IV and + III, i.e. electroreduction of $\mathrm{Tc}(\mathrm{IV})$ to unstable $\mathrm{Tc}(\mathrm{III})$, or possible synproportionation of Tc(III) with pertechnetates(VII). One of the possible reactions taking place in this potential range can be schematically represented as:

$$
\begin{aligned}
& \mathrm{Tc}(\mathrm{IV})+\mathrm{e}^{-} \rightarrow \mathrm{Tc}(\mathrm{III}) \\
& \mathrm{xTc}(\mathrm{III})+\mathrm{yTc}(\mathrm{VII}) \\
& \quad+\mathrm{zH}^{+} \rightleftharpoons\left[\mathrm{Tc}(\mathrm{III} / \mathrm{IV})_{(x+y)} \mathrm{O}_{\mathrm{q}}\right]_{\text {poly }}+\mathrm{wH}_{2} \mathrm{O}
\end{aligned}
$$


Till now the mechanism of formation of polymeric $\mathrm{Tc}(\mathrm{III} / \mathrm{IV}$ or IV) is unclear. It should be noted, however, that these forms are always observed during the reduction of pertechnetates in acidic solutions and their concentration becomes greater when concentration of the pertechnatets increases.

The shape of anodic sections of voltammetric curves recorded for pertechnetates using Au electrodes strongly depends on the concentration of the former. Hence, for $0.5 \mathrm{mM} \mathrm{TcO}_{4}{ }^{-}$investigated in our earlier studies [23] three, partially overlapped, oxidation peaks are observed while for a $5 \mathrm{mM}$ pertechnetates solutions a single, poorly shaped oxidation peak is seen in potential range of $0.5-1 \mathrm{~V}$ (Fig. 2). A striking feature of the curves recorded for the higher concentrations of the pertechnetates is the absence of the oxidation peak at $0.4 \mathrm{~V}$ reported for lower $\mathrm{TcO}_{4}{ }^{-}$ concentration (see in [23]). This peak is attributed to the oxidation of strongly reduced Tc species to Tc(IV). Such evolution of cyclic voltammetry signals recorded for pertechnetates may be attributed to the synproportionation process takes place between $\mathrm{Tc}(\mathrm{III})$ and $\mathrm{Tc}(\mathrm{VII})$ according to Eq. 5 .

The influence of $\mathrm{Np}$ presence on the electrochemical behavior of Tc strongly depends on the form of neptunium species. Thus, the CV curve recorded for the pertechnetates in the presence of $\mathrm{Np}(\mathrm{IV})$ (Fig. 2, dotted line) is very similar to the one recorded in the solutions containing pertechnetates only (Fig. 2, solid line). In $4 \mathrm{M} \mathrm{H}_{2} \mathrm{SO}_{4}$ the $\mathrm{Np}(\mathrm{IV})$ ions prove to be very resistant to the electrooxidation/electroreduction and do not interact with intermediate reduced technetium species generated in processes which generate currents seen on the catodic and anodic branches of $\mathrm{CV}$.

Significant changes in the shape of currents due to electrochemical reactions of Tc are observed when two other forms of $\mathrm{Np}$ are added to the electrolyte, i.e. $\mathrm{Np}(\mathrm{VI})$ and $\mathrm{Np}$ (III). The strongest impact on the currents due to Tc reactions is observed for the electrolyte containing $\mathrm{Np}^{3+}$ (Fig. 2, dashed line). Immediately after mixing of $\mathrm{Np}^{3+}$ and $\mathrm{TcO}_{4}{ }^{-}$solutions a red-ox reaction between $\mathrm{Np}$ (III) and $\mathrm{Tc}(\mathrm{VII})$ takes place. As a result, a change in the color of the solution is observed due to formation of reduced Tc. The reduction of the latter leads to formation of a huge cathodic peak at ca. $0.1 \mathrm{~V}$ which can be attributed to transformation of $\mathrm{Tc}(\mathrm{IV})$ into Tc in lower oxidation states.

An excess of $\mathrm{NpO}_{2}{ }^{2+}$ ions in respect to $\mathrm{TcO}_{4}{ }^{-}$concentration has a strong impact on currents due to pertechnetates reduction (Fig. 2 dashed-dotted line). A significant decrease in the intensity of the first $\mathrm{TcO}_{4}{ }^{-}$reduction peak at $0.5 \mathrm{~V}$ due to $\mathrm{Np}$ presence is noticeable.

The clear impact of $\mathrm{Np}(\mathrm{VI})$ ions on the evolution of $\mathrm{CVs}$ is especially visible when the cyclic voltammograms with fixed scan rate and various cathodic vertex potentials are compared (Fig. 3).

$\mathrm{Np}(\mathrm{VI})$ as a strong oxidizing agent $\left(E_{\mathrm{NpVI} / \mathrm{NpV}}^{0}=\right.$ $1.136 \mathrm{~V}[6])$ can oxidize intermediate technetium (V and VI) species generated in the first step of the pertechnetates electroreduction (Eq. 1), according to the Eq. 6:

$$
\begin{aligned}
\mathrm{Tc}^{\mathrm{V}} \mathrm{O}^{3+}+2 \mathrm{NpO}_{2}^{2+}+3 \mathrm{H}_{2} \mathrm{O} \rightarrow & \mathrm{Tc}^{\mathrm{VII}} \mathrm{O}_{4}^{-}+2 \mathrm{NpO}_{2}^{+} \\
& +6 \mathrm{H}^{+}
\end{aligned}
$$

Reaction (6) leads to a decrease in the concentration of $\mathrm{Tc}(\mathrm{V})$ at the electrode surface. Its disappearance is manifested by a significant decrease of the intensity of the peak at $0.55 \mathrm{~V}$ (Fig. 3, panel B). An opposite effect is observed for the second peak of Tc reduction (at $0.35 \mathrm{~V}$ ) which becomes higher and sharper in the presence of Np. This effect can be attributed to generation of technetium(IV). Reaction (7) is an example of this type of the process:

$\mathrm{Tc}^{\mathrm{VII}} \mathrm{O}_{4}^{-}+6 \mathrm{H}^{+}+3 \mathrm{e}^{-} \rightarrow \mathrm{Tc}^{\mathrm{IV}} \mathrm{O}^{2+}+3 \mathrm{H}_{2} \mathrm{O}$

A quasi-reversible $\mathrm{Np}(\mathrm{VI}) / \mathrm{Np}(\mathrm{V})$ redox system is observed at the potentials $0.6-1.1 \mathrm{~V}$ (Fig. 2, dashed-dotted line). This red-ox couple is characterized by the half-width potential of $0.885 \mathrm{~V}$ which is greater than for any known $\mathrm{Tc}(\mathrm{VII}) / \mathrm{Tc}$ (reduced species) redox system. This potential value, as well as the values of the heterogenous rate constant $\left(0.44 \mathrm{~cm} \mathrm{~s}^{-1}\right)$ and of the product of number of exchanged electrons and the transfer coefficient $(0.39)$ are in line with the literature data for $\mathrm{Np}(\mathrm{V}) / \mathrm{Np}(\mathrm{VI})$ red-ox couple in sulfate solutions [24]. Obviously, all these values are not affected by the presence of pertechnetates.

The Vis-NIR experiments with $\mathrm{Np}(\mathrm{III}) / \mathrm{Tc}(\mathrm{VII})$ reveal that reduction of pertechnetates by $\mathrm{Np}(\mathrm{III})$ is fast and is completed within few minutes as has been shown in Fig. 4. $\mathrm{Np}$ (III) converts $\mathrm{Tc}(\mathrm{VII})$ ions to the polymeric $\mathrm{Tc}(\mathrm{IV})$

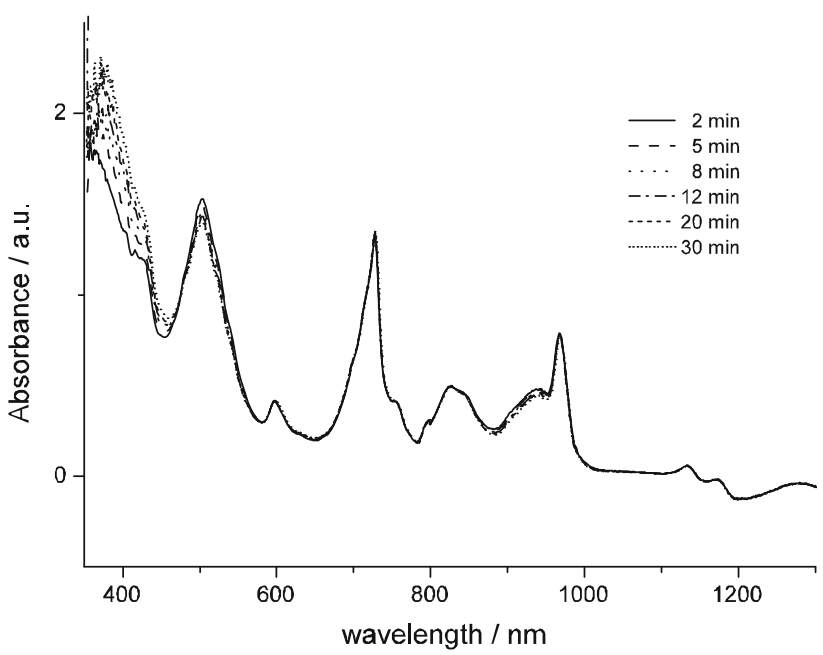

Fig. 4 Evolution of Vis-NIR spectra recorded in $4 \mathrm{M} \mathrm{H}_{2} \mathrm{SO}_{4}$ containing $5 \mathrm{mM} \mathrm{TcO}_{4}{ }^{-}$and $11 \mathrm{mM} \mathrm{Np}^{3+}$ 
species characterized spectroscopically by a band at $500 \mathrm{~nm}$. During this process $\mathrm{Np}$ (III) is oxidized to $\mathrm{Np}(\mathrm{IV})$.

The pair of redox peaks seen at $0.3-0.6 \mathrm{~V}$ in Fig. $3 \mathrm{~A}$ was further investigated using a separately prepared solution which initially contained pertechnetates and $\mathrm{Np}$ (III) ions. The ratio of the initial concentrations of $\mathrm{Tc}(\mathrm{VII})$ and $\mathrm{Np}$ (III) ions (1:3) in this solution reflected the stoichiometry of the reaction (8).

$$
\begin{aligned}
\mathrm{Tc}^{\mathrm{VII}} \mathrm{O}_{4}^{-}+3 \mathrm{~Np}^{3+}+6 \mathrm{H}^{+} \rightarrow & \mathrm{Tc}^{\mathrm{IV}} \mathrm{O}^{2+}+3 \mathrm{~Np}^{4+} \\
& +3 \mathrm{H}_{2} \mathrm{O}
\end{aligned}
$$

Under such conditions the $\mathrm{Tc}(\mathrm{VII})$ are completely reduced to $\mathrm{Tc}(\mathrm{IV})$ by $\mathrm{Np}^{3+}$ ions and the electrolyte is free of pertechnetates as long as the anodic vertex potential of the working electrode is kept too low as for electrochemical formation of $\mathrm{Tc}(\mathrm{V})$ and regeneration of $\mathrm{Tc}(\mathrm{VII})$. When the $\mathrm{Tc}(\mathrm{V})$ species appear, one may expect generation of pertechnetates in purely chemical reactions, such as disproportionation of $\mathrm{Tc}(\mathrm{V})$. The voltammetric curves recorded in such prepared electrolyte are shown in Fig. 5. The $\mathrm{Np}^{4+}$ species formed in reaction (8) are electrochemicaly inactive in the investigated potential range and the observed faradaic currents are attributed exclusively to the reactions of Tc species. Although the pair of redox peaks seen in Fig. 5 is apparently similar to that observed in Fig. 3a at a similar potential range the both pairs of peaks differ in respect to the peaks separation. The distance between anodic and cathodic peaks seen in Fig. 5 is much greater than in the case of Fig. 3a and strongly exceeds $0.1 \mathrm{~V}$. Clearly, at least one of the electrochemical reactions connected with the redox peaks seen in Fig. 5 is not the same as in the case of the peaks observed in $0.3-0.4 \mathrm{~V}$ range in Fig. 3A. The latter currents are attributed to quasireversible or reversible reactions of $\mathrm{Tc}(\mathrm{III} / \mathrm{IV}) / \mathrm{Tc}(\mathrm{IV})$

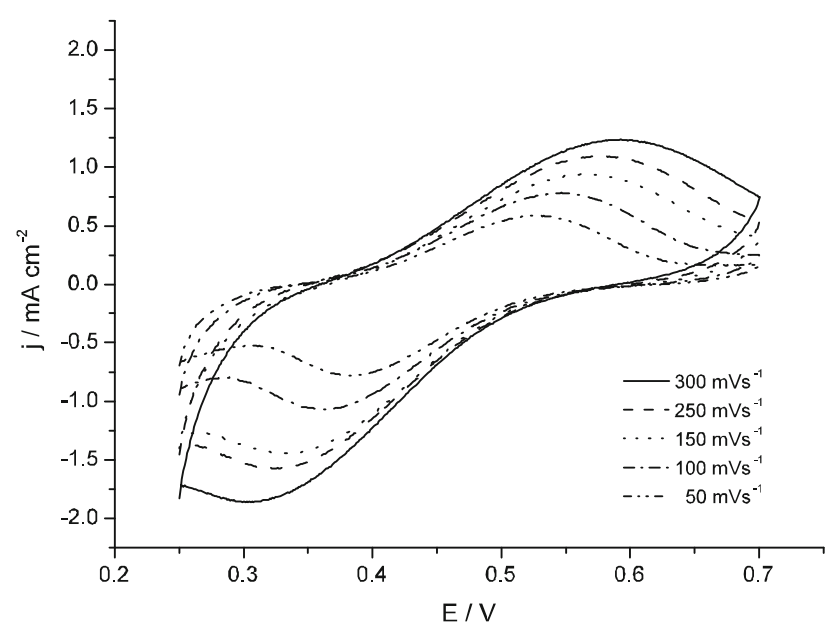

Fig. 5 Cyclic voltammograms recorded in $3.6 \mathrm{mM} \mathrm{TcO}_{4}{ }^{-}+11 \mathrm{mM}$ $\mathrm{Np}^{3+}+4 \mathrm{M} \mathrm{H}_{2} \mathrm{SO}_{4}$, with Au electrode and various scan rates redox couple. In contrast to Fig. $3 \mathrm{~A}$, the separation of cathodic and anodic peaks shown in Fig. 5 is too high to be classified as a reversible or even quasi reversible system [25]. It is likely then that the anodic peak seen in Fig. 5 is due to a multistep electrochemical and chemical process of formation of $\mathrm{TcO}_{4}{ }^{-}$from $\mathrm{TcO}^{2+}$ initially present in the electrolyte. On the other hand, the reduction process which is responsible for the formation of the cathodic peak from Fig. 5 cannot be considered as a reaction reversed to the abovementioned formation of $\mathrm{TcO}_{4}{ }^{-}$. It can be suggested that the reduced Tc (IV) forms present in the bulk of the solution diffuse towards the electrode and are electroreduced to Tc(III) and this process leads to formation of cathodic peak in Fig. 5. In a subsequent chemical reaction such generated Tc(III) species can undergo a polymerisation process with participation of Tc(IV). As a result, the polymeric Tc(III/IV) species are produced.

Additional data related to the interactions between $\mathrm{Np}$ and Tc species were delivered from spectrophotometric experiments (Fig. 6). The experiments with $\mathrm{Np}(\mathrm{VI}) /$ Tc(reduced species) reveal that oxidation of $\mathrm{Tc}(\mathrm{red})$ by $\mathrm{Np}$ (VI) is slower than reduction of $\mathrm{Tc}$ (VII) by $\mathrm{Np}$ (III).

The measurements carried out with the solution prepared by mixing technetium(IV) ionic species with $\mathrm{Np}(\mathrm{VI})$ (Fig. 6) show that the interaction of reduced Tc species with neptunyl(VI) ions leads to formation of intermediate Tc species characterized spectroscopically by a band with the maximum at $460 \mathrm{~nm}$. $\mathrm{Np}$ is the only oxidizing agent present in the solution and is able to oxidize reduced Tc species with formation of the above mentioned intermediates.

The reduced Tc forms characterized spectroscopically by various bands and seen in Fig. 6 are oxidized by $\mathrm{Np}(\mathrm{VI})$. The slowest rate of this process was attained for the $\mathrm{TcO}_{2}$ /polymeric Tc(IV) species (Fig. 6). Oxidation of all reduced Tc species leads to formation of the intermediates with the absorption band at 450-500 $\mathrm{nm}$ but only slow oxidation of $\mathrm{TcO}^{2+} /$ polymeric $\mathrm{Tc}(\mathrm{IV})$ produces the intermediates observed for as long as several minutes with a well-developed band at $460 \mathrm{~nm}$. Tc(V) is the possible species which can be linked with this absorption band. A very slow rate of disappearance of the $\mathrm{Tc}(\mathrm{V})$ band near $460 \mathrm{~nm}$ observed for $\mathrm{TcO}_{2}$ solution indicates that the rate of oxidation of the former species is lower as compared to Tc(III).

The $\mathrm{Np}(\mathrm{VI})$ signal at $1220 \mathrm{~nm}$ evolves only during initial period of ca. few minutes from the start of the reaction, later on the signal becomes apparently unchanged. For all investigated redox $\mathrm{Tc}$ (reduced)/ $\mathrm{Np}(\mathrm{VI})$ systems the band at $980 \mathrm{~nm}$ appears due to formation of $\mathrm{Np}(\mathrm{V})$. This observation indicates that these ions are intermediates in the reduction of neptunyl(VI) ions. The $\mathrm{Np}(\mathrm{V})$ ions are later transformed to $\mathrm{Np}(\mathrm{IV})$ ions. The 

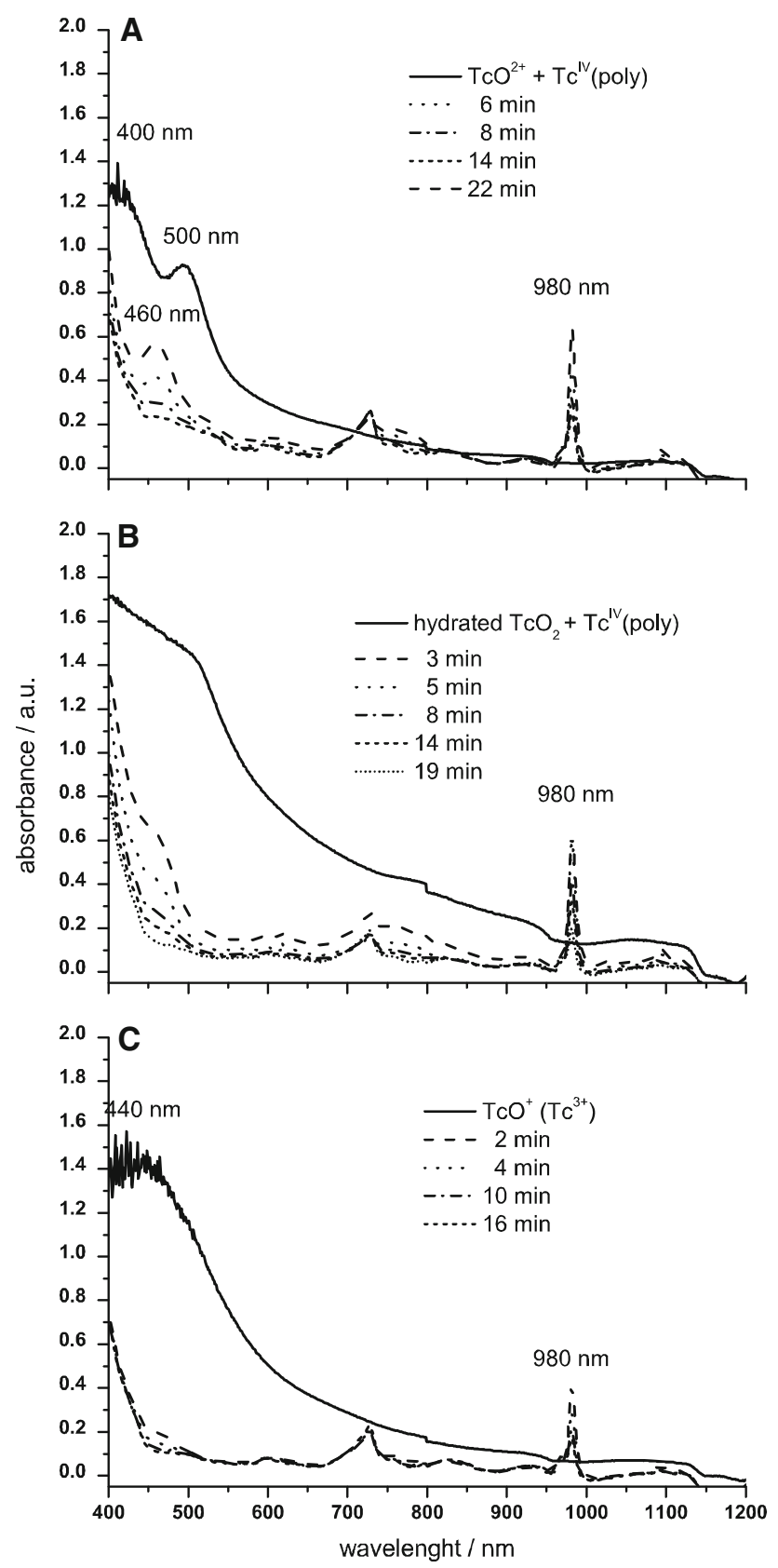

Fig. 6 Evolution of Vis-NIR spectra recorded during redox interaction of $5 \mathrm{mM}$ Tc reduced species: A mixture of $\mathrm{TcO}^{2+}$ and $\mathrm{Tc}(\mathrm{IV})-$ polymer; B hydrated $\mathrm{TcO}_{2}$ and $\mathrm{Tc}(\mathrm{IV})$-polymer; $\mathbf{C ~} \mathrm{TcO}^{+}\left(\right.$or $\mathrm{Tc}^{3+}$ ) with $11 \mathrm{mM} \mathrm{NpO}_{2}^{2+}$ in $4 \mathrm{M} \mathrm{H}_{2} \mathrm{SO}_{4}$

evolution of $\mathrm{Np}(\mathrm{VI})$ concentration with time is much more pronounced than for $\mathrm{Np}(\mathrm{V})$. A continuous decrease in the absorbance of $\mathrm{Np}(\mathrm{V})$ is proportional to the intensity changes of the $460 \mathrm{~nm}$ band of reduced Tc species. The fastest decrease of the latter band is observed for oxidation of $\mathrm{TcO}^{+}$while the slowest rate is recorded during a transformation of $\mathrm{TcO}_{2} / \mathrm{Tc}(\mathrm{IV})$ polymer where the initial step $(\mathrm{Tc}(\mathrm{IV}) \rightarrow \mathrm{Tc}(\mathrm{V}))$ requires structural changes of $\mathrm{Tc}$ forms.

\section{Conclusions}

The behaviour of various technetium species in sulphuric acid solutions in the presence of $\mathrm{Np}^{3+}, \mathrm{Np}^{4+}$ or $\mathrm{NpO}_{2}{ }^{2+}$ ions has been studied. The interaction between $\mathrm{Tc}$ and $\mathrm{Np}$ species with various oxidation states was investigated in an aqueous $4 \mathrm{M} \mathrm{H}_{2} \mathrm{SO}_{4}$ by means of cyclic voltammetry and Vis-NIR spectroscopy. The results obtained in the studies allow drawing the following conclusions:

- $\mathrm{Np}(\mathrm{IV})$ is stable in a strong acidic environment, such as $4 \mathrm{M} \mathrm{H}_{2} \mathrm{SO}_{4}$, and does not interact with Tc species.

- Reduced Tc species with oxidation states lower than $+\mathrm{VII}$ are oxidised by $\mathrm{Np}(\mathrm{VI})$ into pertechnetates via unstable $\mathrm{Tc}(\mathrm{V})$ species. This process leads to formation of $\mathrm{Np}(\mathrm{IV})$ with $\mathrm{Np}(\mathrm{V})$ as an unstable intermediate.

- The rate of the oxidation of Tc reduced forms to pertechnetates depends on their structures and the oxidation state of Tc. Ionic forms of $\mathrm{Tc}(\mathrm{III})$ are completely oxidized to $\mathrm{TcO}_{4}{ }^{-}$within few minutes in opposite to $\mathrm{TcO}_{2}$ or $\mathrm{Tc}(\mathrm{IV})$ polymers for which this process takes about $20 \mathrm{~min}$.

Acknowledgements This work was financially supported by Talisman Project (TaliC05-11) in the frame of Euratom 7 Programm and by Faculty of Chemistry, University of Warsaw, Grant No. DSM-107 500. The author thanks Stephan Weiss from HZDR-HelmholtzZentrum Dresden-Rossendorf for preparation of Mn, Tc and Np stock solutions.

Open Access This article is distributed under the terms of the Creative Commons Attribution 4.0 International License (http://creative commons.org/licenses/by/4.0/), which permits unrestricted use, distribution, and reproduction in any medium, provided you give appropriate credit to the original author(s) and the source, provide a link to the Creative Commons license, and indicate if changes were made.

\section{References}

1. IAEA Report (1996) Selected radionuclides important to lowlevel radioactive waste management (DOE/LLW-238), Vienna

2. Vondy DR, Lane JA, Gresky AT (1964) Production of Np-237 and $\mathrm{Pu}-238$ in thermal power reactors. Ind Eng Chem Process Des Dev 3:293-296

3. Bonnerot JM, Broudic V, Phélip M, Jégou C, Varaine F, Deschanels X, Arnoux MF, Faugère JL (2005) Transmutation in reactor and aqueous corrosion resistance of technetium metal. J Nucl Radiochem Sci 6(3):287-290

4. Yoshida Z, Johnson SG, Kimura T, Krsul JR (2006) In: Morss LR, Edelstein N, Fuger J, Katz JJ (eds) The chemistry of actinides and transactinides elements, chapter 6, vol 2. Springer, Berlin

5. Rard J, Rand MH, Anderegg G, Wanner H (1999) Chemical thermodynamics of technetium, vol 3. Elsevier, Amsterdam

6. Chairman HG, Lemire RJ (2001) Chemical thermodynamics of neptunium and plutonium, vol 4. Elsevier, Amsterdam

7. Marchenko VI, Zhuravleva GI, Dvoeglazov KN, Savilova OA (2008) Behaviors of plutonium and neptunium in nitric acid 
solutions containing hydrazine and technetium ions. Theor Found Chem Eng 42(5):733-739

8. Ozawa M, Ishida M, Sano Y (2003) Strategic separation of technetium and rare metal fission products in spent nuclear fuel: solvent extraction behavior and partitioning by catalytic electrolytic extraction. Radiochemistry 45(3):225-232

9. Zhou X, Ye G, Zhang H, Li L, Luo F, Meng Z (2014) Chemical behavior of neptunium in the presence of technetium in nitric acid media. Radiochim Acta 102(1-2):111-116

10. Chotkowski M, Czerwinski A (2014) Thin layer spectroelectrochemical (RVC-OTTLE) studies of pertechnetate reduction in acidic media. J Radioanal Nucl Chem 300(1):229-234

11. Rotmanov V, Maslennikov AG, Zakharova LV, Goncharenko YuD, Peretrukhin VF (2015) Anodic dissolution of Tc metal in $\mathrm{HNO}_{3}$ solutions. Radiochemistry 57(1):26-30

12. Maslennikov AG, Courson O, Perettroukhine VE, David F, Masson M (1997) Technetium electrochemical reduction in nitric acid solutions at mercury and carbon electrodes. Radiochim Acta 78(1):123-129

13. Poineau F, Weck PF, Burton-Pye BP, Denden I, Kim E, Kerlin W, German KE, Fattahi M, Francesconi LC, Sattelberger AP, Czerwinski KR (2013) Reactivity of $\mathrm{HTcO}_{4}$ with methanol in sulfuric acid: Tc-sulfate complexes revealed by XAFS spectroscopy and first principles calculations. Dalton Trans 42(13):4348-4352

14. Paquette J, Lawrence WE (1985) A spectroelectrochemical study of the technetium(IV)/technetium(III) couple in bicarbonate solutions. Can J Chem 63:2369-2373

15. Chotkowski M (2016) Extraction of moderate oxidation state technetium species between $30 \%$ tri-n-butyl phosphate and $\mathrm{H}_{2} \mathrm{SO}_{4} / \mathrm{HNO}_{3}$. J Radioanal Nucl Chem 307:457-462

16. Mausolf E, Poineau F, Droessler J, Czerwinski KR (2011) Spectroscopic and structural characterization of reduced technetium species in acetate media. J Radioanal Nucl Chem 288:723-728

17. Vichot L (2001) Spéciation du technétium en milieu chloro-sulfaté. Contribution à l'étude des effets de la radiolyse $\gamma$. Ph.D. thesis, Universite Paris-Sud XI

18. Kitatsuji Y, Kimura T, Kihara S (2010) Reduction behavior of neptunium(V) at a gold or platinum electrode during controlled potential electrolysis and procedures for electrochemical preparations of neptunium(IV) and (III). J Electroanal Chem 641:83-89

19. Sjoblom R, Hindman JC (1951) Spectrophotometry of neptunium in perchloric acid solutions. J Am Chem Soc 73(4):1744-1751

20. Escure $H$ (1974) Studies of $N p(V)$ disproportionation in acid solutions Rapport CEA-R-4574 http://www.iaea.org/inis/collec tion/NCLCollectionStore/_Public/06/177/6177346.pdf?r=1 . Accessed 2 Feb 2018

21. Shilov VP, Gogolev AV, Fedoseev AM (2012) Speciation, stability, and reactions of $\mathrm{Np}(\mathrm{III}-\mathrm{VII})$ in aqueous solutions. Radiochemistry 54:212-227

22. Sullivan JC, Cohen D, Hindman JC (1957) Kinetics of reactions involving neptunium(1 V), neptunium(V) and neptunium(V1) ions in sulfate media. J Am Chem Soc 79(15):4029-4034

23. Chotkowski M, Czerwiński A (2012) Electrochemical and spectroelectrochemical studies of pertechnetate electroreduction in acidic media. Electrochim Acta 76:165-173

24. Ikeda-Ohno A, Hennig Ch, Rossberg A, Funke H, Scheinost AC, Bernhard G, Yaita T (2005) Electrochemical and complexation behavior of neptunium in aqueous perchlorate and nitrate solutions. Inorg Chem 47:8294-8305

25. Bard AJ, Faulklaner LR (2001) Electrochemical methods fundamentals and applications, 2nd edn. Willey, New York 